\title{
Skąpoobjawowa manifestacja ostrego zespołu wieńcowego u 51-letniego mężczyzny bez wywiadu kardiologicznego - indywidualizacja postępowania na podstawie analizy czynników ryzyka choroby wieńcowej
}

\author{
Oligosymptomatic manifestation of acute coronary syndrome in 51-year-old man \\ without cardiologic medical history - individual approach according \\ to coronary artery disease risk factors analysis
}

\author{
Maciej Krzysztof Kluk ${ }^{1}$, Dawid Bąkowski ${ }^{1}$, Beata Wożakowska-Kapłon ${ }^{1,2}$ \\ ${ }^{1}$ I Klinika Kardiologii i Elektroterapii Świętokrzyskiego Centrum Kardiologii w Kielcach \\ ${ }^{2}$ Wydział Nauk o Zdrowiu Uniwersytetu Jana Kochanowskiego w Kielcach
}

\section{Streszczenie}

Choroba niedokrwienna serca (IHD), w tym choroba wieńcowa, wykazuje tendencję do ujawniania się w coraz młodszych populacjach chorych. Wpływają na to zarówno szeroko obecnie występujące klasyczne czynniki ryzyka, takie jak palenie tytoniu czy zaburzenia lipidowe, jak i współczesne czynniki, takie jak przewlekły stres. Jednocześnie IHD często przebiega skąpoobjawowo u młodych chorych, co utrudnia jej prawidłowe rozpoznanie.

Słowa kluczowe: choroba niedokrwienna serca, choroba wieńcowa, ostry zespół wieńcowy, młodzi chorzy

(Folia Cardiologica 2015; 10, 5: 386-390)

\begin{abstract}
Wstęp
Choroba niedokrwienna serca (IHD, ischaemic heart disease), w tym jej postać o etiologii miażdżycowej - choroba wieńcowa (CAD, coronary artery disesase), wykazuje tendencję do ujawniania się w coraz młodszych populacjach chorych, także u osób nieobciążonych wywiadem chorób układu krążenia. Manifestacja kliniczna jest często w tej grupie chorych ubogoobjawowa, niejednokrotnie przyjmując postać ostrego zawału serca lub nagłego zgonu sercowego. Osoby „młode” są narażone na działanie zarówno klasycznych czynników ryzyka miażdżycy, jak i współczesnych czynników środowiskowych na czele z przewlekłym stresem. Przy
\end{abstract}

częstych pozamiażdżycowych przyczynach niedokrwienia mięśnia sercowego w tej grupie chorych niejednokrotnie ma miejsce niedoszacowanie postępu miażdżycy, co może opóźnić rozpoznanie istotnej, choć nietypowo i skąpoobjawowo przebiegającej, miażdżycy.

\section{Opis przypadku}

Mężczyzna w wieku 51 lat, palący papierosy (ok. 1 paczkę/dzień od 15 lat), dotychczas nieleczony kardiologicznie, intensywnie pracujący zawodowo (praca biurowa), z wywiadem rodzinnym choroby wieńcowej u matki leczonej pomostowaniem aortalno-wieńcowym w wieku 64 lat,

Adres do korespondencji: lek. Maciej Krzysztof Kluk, I Klinika Kardiologii i Elektroterapii, Świętokrzyskie Centrum Kardiologii, ul. Grunwaldzka 45, 25-736 Kielce, tel. 41367 13 91/13 88, faks 41367 13 96, e-mail: maciej.kluk@gmail.com 
z rozpoznaną chorobą zwyrodnieniową stawów kręgosłupa w odcinku lędźwiowo-krzyżowym, został skierowany przez lekarza podstawowej opieki zdrowotnej (POZ) na szpitalny oddział ratunkowy (SOR) z powodu podejrzenia ostrego zespołu wieńcowego (ACS, acute coronary syndrome). Chory zgłaszał spoczynkowe dolegliwości o typie drętwienia lewej kończyny górnej, lewej połowy szyi i żuchwy, bez zamostkowej stenokardii, o nagłym początku około 24 godziny wcześniej i zmiennym nasileniu w ciągu doby. Chory zgłosił się do lekarza po kolejnym nawrocie dolegliwości w godzinach porannych następnego dnia. Zapisy badania elektrokardiograficznego (EKG) w poradni oraz przy przyjęciu na SOR nie wykazały cech niedokrwienia mięśnia serca mimo utrzymujących się objawów klinicznych. Spośród odchyleń w badaniu przedmiotowym przy przyjęciu na SOR stwierdzono podwyższone symetrycznie na obu kończynach górnych wartości ciśnienia tętniczego, wynoszącew 160/100 mm Hg. W badaniach laboratoryjnych spośród odchyleń stwierdzono izolowane podwyższone wartości troponiny T wysoczułej (hsTnT, high-sensitive troponin $T$ ) bez typowej dla zawału serca dynamiki wzrostu w kontrolnym oznaczeniu po upływie 3 godzin (odpowiednio 30,7 i 42,9 ng/l przy wartości 99. percentyla $=14,0 \mathrm{mg} / \mathrm{I}$ ). Chory otrzymał następujące leki: kwas acetylosalicylowy w dawce 300 mg doustnie, klopidogrel 300 mg doustnie, kaptopril 25 mg podjęzykowo, $500 \mathrm{ml}$ 0,9-procentowego roztworu chlorku sodu dożylnie, po czym został przyjęty do kliniki kardiologii z podejrzeniem ACS bez przetrwałego uniesienia odcinka ST (NSTE-ACS, non-ST elevation ACS). Przy przyjęciu do kliniki chory podawał ustąpienie dolegliwości i dobre samopoczucie. Wskaźnik masy ciała chorego wynosił $28 \mathrm{~kg} / \mathrm{m}^{2}$. Zapis EKG utrzymywał się w granicach normy, zaś w wykonanym badaniu echokardiograficznym nie stwierdzono nieprawidłowości ani w zakresie funkcji skurczowej lewej komory, ani jam prawego serca, aorty, worka osierdziowego czy zastawek serca. W dodatkowych badaniach laboratoryjnych spośród odchyleń wykazano podwyższone do $153 \mathrm{mg} / \mathrm{dl}$ wartości cholesterolu frakcji LDL (low-density lipoprotein). Wykonano również badanie radiologiczne (RTG) klatki piersiowej i odcinka szyjnego kręgosłupa, stwierdzając zmiany zwyrodnieniowo-wytwórcze. W ciągu dalszej obserwacji w klinice dolegliwości nie nawracały, jak również nie ulegały zmianie kontrolne zapisy EKG. W leczeniu stosowano następujące leki (w nawiasach podano dawki dobowe): kwas acetylosalicylowy (75 mg), klopidogrel (75 mg), pantoprazol (20 mg), ramipril (10 mg), atorwastatynę (80 mg), nebiwolol (2,5 mg), z dobrą tolerancją. Uwzględniając nieznacznie podwyższone wartości hsTnT, ryzyko wewnątrzszpitalnego zgonu lub zawału serca oszacowano w skali GRACE na 67 punktów.
Z powodu stabilnego stanu klinicznego, ACS niskiego ryzyka oraz obecności istotnych czynników ryzyka CAD (wiek, płeć, palenie tytoniu, nadwaga, hipercholesterolemia, nadciśnienie tętnicze) chorego zakwalifikowano do oceny niedokrwienia mięśnia sercowego indukowanego wysiłkiem fizycznym w trakcie trwającej hospitalizacji. Ze względu na ograniczoną dostępność zaawansowanych metod obrazowania obciążeniowego przeprowadzono test wysiłkowy EKG (po odstawieniu beta-adrenolityku w dniu badania), który chory ukończył przed osiągnięciem limitu tętna (77\% tętna maksymalnego) z powodu duszności i zawrotów głowy. W łącznym czasie 11 minut chory wykonał pracę równoważną 12,6 MET bez typowych objawów dławicowych i z maksymalnym poziomym obniżeniem odcinka ST w odprowadzeniu V5 do $1 \mathrm{~mm}$, co łącznie pozwoliło na obliczenie wartości wskaźnika Duke’a (DTS, Duke Treadmill Score) na 6 punktów (niskie ryzyko zgonu w ciągu roku). Kolejnego dnia zaplanowano wypisanie chorego do domu, rutynowo zlecając kontrolne badania laboratoryjne, w tym oznaczenie enzymów martwicy mięśnia sercowego, oraz badanie EKG. W godzinach porannych dnia następnego po próbie wysiłkowej stwierdzono wzrost wartości hsTnT (459,8 ng/l) przy prawidłowych stężeniach kinazy kreatynowej, izoenzymu sercowego kinazy kreatynowej i kreatyniny. Jednoczasowo istotnie wzrosło stężenie białka C-reaktywnego (CRP, C-reactive protein) - z 1,64 do $69,96 \mathrm{mg} / \mathrm{dl}$. Zmiany parametrów laboratoryjnych potwierdzono w kolejnych oznaczeniach (hsTnT - 380,9 i 185,0 ng/l, CRP - 21,08 mg/dl). Wzrostowi markerów nie towarzyszyły dolegliwości kliniczne, w tym gorączka, ani zmiany w zapisie EKG, natomiast w kontrolnym badaniu echokardiograficznym stwierdzono dyskretną hipokinezę segmentów okołokoniuszkowych lewej komory. Ze względu na potwierdzenie martwicy mięśnia sercowego chorego zakwalifikowano do diagnostyki inwazyjnej tętnic wieńcowych. W wykonanej angiografii wieńcowej stwierdzono istotne zwężenia w obrębie środkowego odcinka prawej tętnicy wieńcowej (ryc. 1), gdzie skutecznie implantowano stent powlekany lekiem antymitotycznym, oraz drugiej tętnicy brzeżnej (ryc. 2), gdzie wykonano angioplastykę balonową z dobrym efektem hemodynamicznym, uprzednio dokonując konwersji leczenia przeciwpłytkowego z klopidorelu na tikagrelor zgodnie z aktualnymi wytycznymi Europejskiego Towarzystwa Kardiologicznego (ESC, European Society of Cardiology) dotyczącymi rewaskularyzacji wieńcowej [1]. Dalsza hospitalizacja przebiegała stabilnie, co umożliwiło wypisanie chorego do domu w 2. dobie po leczeniu zabiegowym. W zaleceniach lekarskich wyraźnie podkreślono szczególną rolę zaprzestania palenia tytoniu przez pacjenta w ramach prewencji wtórnej incydentów sercowo-naczyniowych. 


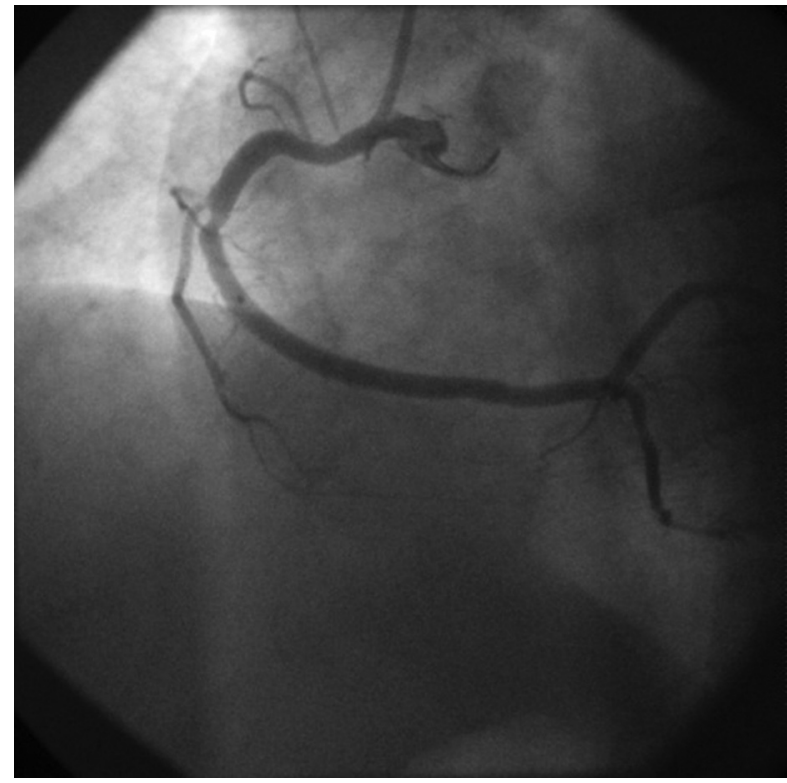

Rycina 1. Istotne zwężenie w odcinku środkowym prawej tętnicy wieńcowej

\section{Omówienie}

Chorobowość i umieralność związane z przedwczesnym rozwojem IHD (w tym przede wszystkim CAD) stanowią istotny problem zdrowotny w populacjach krajów wysoko uprzemysłowionych, w których społeczeństwo w wieku produkcyjnym jest narażone na działanie nie tylko klasycznych czynników ryzyka rozwoju miażdżycy, lecz również na addytywną presję współczesnych czynników środowiskowych, takich jak czynniki psychospołeczne na czele z przewlekłym stresem, zaburzenia snu, zanieczyszczenie środowiska, proaterogenne nawyki żywieniowe, zwiększenie występowania otyłości w wieku dziecięcym i młodzieńczym. Jednocześnie w badaniu NATPOL 2002 wykazano, że tradycyjne czynniki ryzyka rozwoju miażdżycy coraz częściej występują w populacji osób młodych, tj. od 30. do 50. roku życia, szczególnie w przypadku palenia tytoniu i dyslipidemii [2]. Wiek stanowi klasyczny niepoddający się modyfikacji czynnik ryzyka sercowo-naczyniowego, przy czym udowodniono jego różny wpływ zależny od płci - u mężczyzn ryzyko objawowej CAD staje się istotne powyżej 45. roku życia, u kobiet zaś - powyżej 55. roku życia [3]. Epidemiologia, symptomatyka oraz rokowanie w IHD u chorych w tak zwanym młodym wieku pozostają przedmiotem badań ze względu na trudności w oszacowaniu skali problemu związane z często skąpoobjawowym przebiegiem choroby, jak również trudności z precyzyjnym zdefiniowaniem badanej populacji. Z tego powodu wzrasta również prawdopodobieństwo nierozpoznania choroby w początkowym okresie jej manifestacji klinicznej. Maroszyńska-Dmoch i Wożakowska-Kapłon [4] przeprowadziły podsumowanie stanu wiedzy na temat IHD

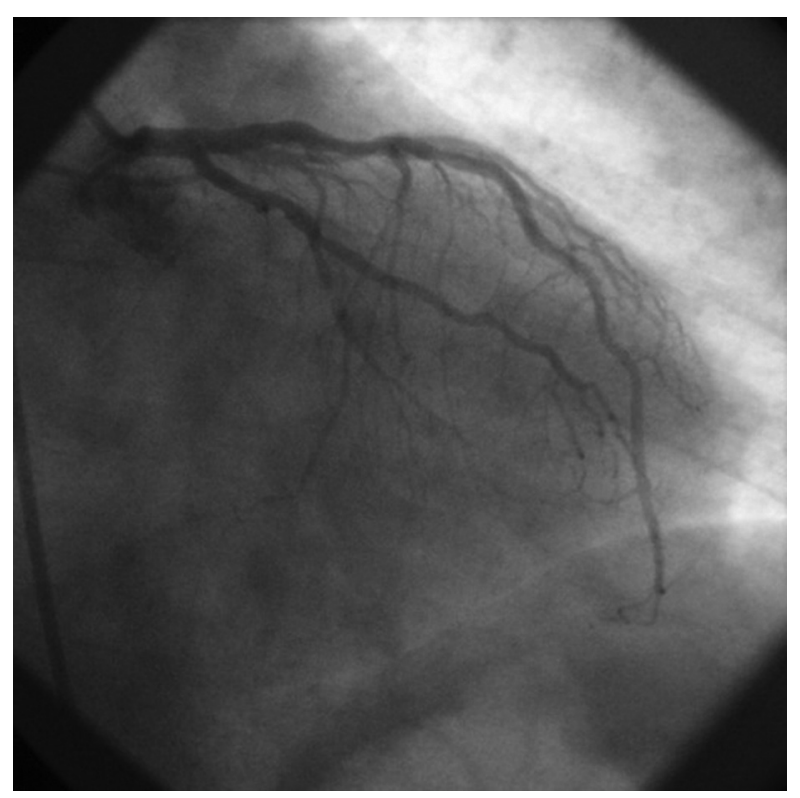

Rycina 2. Zwężenie w odcinku środkowym tętnicy okalającej drugiej

w grupie pacjentów poniżej 45. roku życia, wskazując na różnorodność etiologii niedokrwienia z relatywnie rzadszym w stosunku do osób starszych występowaniem istotnej angiograficznie miażdżycy tętnic wieńcowych, przeważającą manifestację kliniczną w postaci ACS (szczególnie zawał serca z przetrwałym uniesieniem odcinka ST), względnie korzystne rokowanie krótkoterminowe przy wątpliwych danych na temat rokowania odległego oraz brak efektywnych metod selekcji chorych w młodym wieku najbardziej zagrożonych nagłym zgonem z powodu nierozpoznanej IHD. W swojej pracy autorki te podkreśliły, że u 80\% chorych z zawałem serca przed 45. rokiem życia choroba ma podłoże miażdżycowe, natomiast najczęstszy profil kliniczny ryzyka to palący papierosy mężczyzna z zaburzeniami gospodarki lipidowej [4].

Odnosząc prezentowany przypadek kliniczny do powyższych danych, łatwo zauważyć podobieństwo chorego do typowego profilu młodego chorego zagrożonego zawałem serca; chory to mężczyzna w młodym wieku co prawda powyżej 45. roku życia, a więc znajdujący się w grupie klasycznego ryzyka wieńcowego związanego z wiekiem u płci męskiej, palący tytoń i cechujący się podwyższonymi wartościami cholesterolu. U chorego ponadto addytywnie działały również inne czynniki ryzyka, tj. dotychczas nieleczone nadciśnienie tętnicze, nadwaga oraz prawdopodobnie stres związany z obowiązkami zawodowymi. Pierwotnie, w trakcie pobytu na SOR, u tego pacjenta stwierdzono jeszcze nietypowe dolegliwości bólowe, podwyższone wartości ciśnienia tętniczego i podwyższone stężenie hsTnT. Biorąc pod uwage płeć chorego, wiek i wywiad palenia papierosów, 
lekarz dyżurny przyjął chorego do szpitala w celu poszerzenia diagnostyki. Jak się następnie okazało - słusznie. Zgodnie z intencją przyjęcia wobec chorego zastosowano postępowanie zgodne z zaleceniami ESC dotyczącymi chorych z NSTE-ACS [5]. Postępowanie u tego chorego było jednak istotnie utrudnione pod kilkoma względami. Przede wszystkim ocena bólu w klatce piersiowej pierwotnie była niejednoznaczna - drętwienie lewej kończyny górnej i żuchwy, nawracające i ustępujące od ponad 6 godzin, nie pozwalało jednoznacznie zaklasyfikować dolegliwości, choć z pewnością w przypadku dolegliwości dławicowych należałoby mówić o świeżo ujawnionej dławicy. Istotnym czynnikiem budzącym wątpliwości w tym przypadku było stwierdzenie stężenia hsTnT 2-krotnie przekraczającego 99. percentyl, jednakże bez istotnej dynamiki wzrostu po zalecanych 3 godzinach obserwacji. Dodatkowo nie zwiększyły się także inne enzymatyczne wykładniki martwicy mięśnia sercowego ani nie stwierdzono specyficznych zmian w badaniu EKG. W diagramach postępowania we wspomnianych wytycznych jest mowa o konieczności przeprowadzenia diagnostyki różnicowej przyczyn dolegliwości bólowych w klatce piersiowej w przypadku 2-krotnie podwyższonych powyżej górnej granicy normy stężeń troponiny przy braku istotnej dynamiki stężenia. U opisywanego chorego przeprowadzono tego typu diagnostykę - badanie echokardiograficzne i RTG klatki piersiowej pozwoliły wykluczyć inne istotne przyczyny objawów klinicznych i granicznego wzrostu stężenia troponiny. Zważywszy na czynniki ryzyka miażdżycy, także nowo rozpoznane, takie jak hipercholesterolemia, podtrzymano podejrzenie ACS. W monitorowaniu zapisu EKG nie ujawniono specyficznych zmian niedokrwiennych, co klasyfikowało chorego w grupie NSTE-ACS. W trakcie hospitalizacji nie stwierdzono czynników wysokiego ryzyka ACS według wytycznych ESC [5] - podwyższone wartości troponin nie były istotnie wysokie i pierwotnie nie wykazywały typowej dynamiki. Przeprowadzona ocena w skali GRACE wskazała natomiast na niskie ryzyko zgonu wewnątrzszpitalnego lub wystąpienia zawału serca. Wobec braku zarówno nawrotu dolegliwości, jak i elektrokardiograficznych i echokardiograficznych wykładników ostrego niedokrwiennego uszkodzenia mięśnia sercowego chorego, zgodnie z zaleceniami, zakwalifikowano do oceny nieinwazyjnej. Ze względu na młody wiek, płeć męską, dobre warunki fizyczne do podjęcia kontrolowanego wysiłku fizycznego i brak wtórnych zmian odcinka ST w EKG przeprowadzono próbę wysiłkową według protokołu Bruce'a pod kontrolą EKG po uprzednim odstawieniu beta-adrenolityku. Wykazano w niej maksymalnie 1-milimetrowe obniżenia odcinka ST w jednym odprowadzeniu, aczkolwiek test okazał się nie w pełni diagnostyczny, ponieważ chory ukończył go przedwcześnie z powodu ogólnego zmęczenia i zawrotów głowy. Wskaźnik DTS obliczony dla wysiłku podjętego przed uzyskaniem limitu tętna wyniósł 6 punktów, co wskazywało na niskie ryzyko związane z ewentualną rezydualną CAD u chorego. Dobór testu wysiłkowego EKG był dodatkowo poparty faktem, że możliwość oceny wskaźnika Duke'a, jako względnie obiektywnego czynnika rokowniczego, została pierwotnie udowodniona w grupie mężczyzn [6], choć jego wartość diagnostyczną i rokowniczą potwierdzono następnie również u kobiet [7]. Całość obrazu klinicznego wpłynęła na decyzję o leczeniu zachowawczym chorego i kontroli czynników ryzyka CAD na obecnym etapie. Zgodnie z praktyką kliniczną stosowaną w I Klinice Kardiologii i Elektroterapii Świętokrzyskiego Centrum Kardiologii w Kielcach przed planowanym wypisaniem chorego do domu oznaczono u niego jednak kontrolne wartości enzymów martwicy mięśnia sercowego oraz wykonano kontrolny zapis EKG. Ku zaskoczeniu zespołu leczącego kontrolne stężenie hsTnT po teście wysiłkowym wykazało istotny wzrost względem ostatnio oznaczonej wartości (mimo braku objawów klinicznych, zmian wartości innych enzymów martwicy mięśnia sercowego i zmian w spoczynkowym zapisie EKG, choć z dyskretnymi zmianami odcinkowej kurczliwości mięśnia lewej komory). Potwierdzono tym samym obecność martwicy mięśnia sercowego z następczą kwalifikacją do diagnostyki inwazyjnej tętnic wieńcowych, w której uwidoczniono typową lokalizację skąpoobjawowych zmian miażdżycowych - w dorzeczu gałęzi okalającej oraz w prawej tętnicy wieńcowej.

W tym przypadku jedno dodatkowe - niepodyktowane sytuacją kliniczną, a bardziej rutynową praktyką - oznaczenie pierwotnie wątpliwych wartości biomarkerów martwicy mięśnia sercowego przesądziło o wykryciu istotnych zwężeń w tętnicach wieńcowych. Pozostaje pytanie czy zmiany te - przy wcześniej ocenianych niskich wskaźnikach ryzyka ACS - musiałyby skutkować w przyszłości incydentem wieńcowym istotnie zagrażającym choremu? Tego nie wiadomo, chociaż istotne punktowe zmiany w dorzeczu zarówno lewej, jak i prawej tętnicy wieńcowej zapewne w przyszłości ujawniłby się klinicznie - oby nie w postaci nagłego zgonu sercowego. Zmiany w tętnicach spowodowały pierwszą manifestację kliniczną CAD u względnie młodego chorego - przebiegającą skąpoobjawowo i nietypowo, z granicznymi wskaźnikami niedokrwienia mięśnia sercowego zarówno w badaniach laboratoryjnych, jak i w próbie obciążeniowej. Warto podkreślić znaczenie oceny czynników ryzyka u dotąd niewykazującego objawów i nieleczonego chorego - z uwagi na płeć i wiek znajdował się on pierwotnie, dopóki nie wystąpiły u niego tak nagłe objawy kliniczne, w grupie pośredniego ryzyka choroby wieńcowej, co już nakazywałoby diagnostykę nieinwazyjną [8]. Jednakże dodatkowe klasyczne czynniki, takie jak palenie tytoniu, nowo rozpoznane nadciśnienie tętnicze, hipercholesterolemia i nadwaga, oraz czynniki nieklasyczne, takie jak stres, nakazywały dużą ostrożność w ocenie chorego. Ze względu na kliniczne cechy NSTE-ACS przy przyjęciu do 
szpitala wdrożono typowe leczenie włącznie z podwójną terapią przeciwpłytkową. Pierwotnie granicznie podwyższone wartości hsTnT nie pozwalały jednak na jednoznaczne rozpoznanie ostrego niedokrwiennego uszkodzenia mięśnia sercowego zgodnie z zaleceniami ESC dotyczącymi postępowania w NSTE-ACS (większy nacisk na dynamikę wzrostu wartości enzymów niż bezwzględne wartości [5]) - ich bezwzględne wartości obligowały natomiast do wzmożonej czujności i monitorowania pacjenta, co udało się w tym przypadku efektywnie zrealizować.

\section{Podsumowanie}

Ostry zespół wieńcowy, będący wyrazem niestabilności blaszki miażdżycowej, klinicznie jest stanem zagrożenia życia o przebiegu dynamicznym. Na rozpoznanie składają się objawy klinicznie, analiza badania EKG, badania laboratoryjne oraz dodatkowe badania obrazowe. Szczególnie
NSTE-ACS w badaniu EKG, który może przebiegać bez zmian niedokrwiennych w obrazie elektrokardiograficznym i echokardiograficznym, jest stanem trudnym do rozpoznania w grupie osób młodszych, często z nietypowymi dolegliwościami i niewielką dynamiką zmian stężeń laboratoryjnych markerów niedokrwienia miokardium. Trudności i wątpliwości diagnostyczne są wyrażone również w zaleceniach ESC dotyczących NSTE-ACS. Ważnym elementem oceny chorego w młodszym wieku z obrazem klinicznym sugerującym ACS jest wywiad w kierunku czynników ryzyka sercowo-naczyniowego, szczególnie palenia tytoniu i dyslipidemii, co powinno nakazywać szczególną czujność diagnostyczną nawet mimo braku innych wykładników ACS.

\section{Konflikt interesów}

Autorzy nie zgłaszają konfliktu interesów.

\section{Abstract}

Ischaemic heart disease (IHD), including coronary artery disease, tends to manifest in younger population of cardiologic patients. This process is accelerated by presence of classic coronary artery heart disease risk factors as smoking or dyslipidaemia, as well as contemporary ones as chronic stress. In younger population IHD is often oligosymptomatic which makes it difficult to diagnose correctly.

Key words: ischaemic heart disease, coronary artery disease, acute coronary syndrome, young patients

(Folia Cardiologica 2015; 10, 5: 386-390)

\section{Piśmiennictwo}

1. Windecker S., Kolh P., Alfonso F. i wsp. 2014 ESC/EACTS Guidelines on myocardial revascularization The Task Force on Myocardial Revascularization of the European Society of Cardiology (ESC) and the European Association for Cardio-Thoracic Surgery (EACTS). Eur. Heart J. 2014; 35: 2541-2619.

2. Zdrojewski T., Bandosz P., Szpakowski P. i wsp. Rozpowszechnienie głównych czynników ryzyka chorób układu sercowo-naczyniowego w Polsce. Wyniki badania NATPOL-plus. Kardiol. Pol. 2004; 61: 1-26.

3. De Backer G., Ambrosioni E., Borch-Johnsen K. i wsp. Third Joint Task Force of European and other Societies on Cardiovascular Diseases Prevention in Clinical Practice. European guidelines on cardiovascular diseases prevention in clinical practice. Eur. Heart J. 2003; 24 : 1601-1610.

4. Maroszyńska-Dmoch E., Wożakowska-Kapłon B. Choroba wieńcowa w populacji młodych dorosłych: skala problemu, czynniki ryzyka i rokowanie - przegląd literatury. Folia Cardiol. 2014; 9: 267-274.
5. Hamm C.W., Bassand J.P., Agewall S. i wsp. ESC Guidelines for the management of acute coronary syndromes in patients presenting without persistent ST-segment elevation: The Task Force for the management of acute coronary syndromes (ACS) in patients presenting without persistent ST-segment elevation of the European Society of Cardiology (ESC). Eur. Heart J. 2011; 32: 2999-3054.

6. Mark D.B., Hlatky M.A., Harrell F.E. Jr i wsp. Exercise treadmill score for predicting prognosis in coronary artery disease. Ann. Intern. Med. 1987; 106: 793-800.

7. Alexander K.P., Shaw L.J., Delong E.R. i wsp. Value of exercise treadmill testing in women. JACC 1998; 32: 1657-1664.

8. Montalescot G., Sechtem U., Achenbach S. i wsp. 2013 ESC guidelines on the management of stable coronary artery disease: the Task Force on the management of stable coronary artery disease of the European Society of Cardiology. Eur. Heart J. 2013; 34: 2949-3003. 